\title{
Can formal banks be a sole facilitator of firm's financial needs? - A brief outlook on Indian financial sector
}

\author{
Dr. Thresi Varghese \\ Assistant Professor, \\ Sohar University, Oman
}

\begin{abstract}
This paper will shed some light on the funding of businesses in India .The financial performance of India's business sector has been under stress since many years. Balance-sheet data on a large cross-section of Indian non-financial businesses show that the growth in their power over the last 15 years has been associated with an outstanding increase in the liabilities of firms carrying high interest payment burdens. Judged by the debt carried by the most exposed component of firms, the Indian corporate sector's problem to severe systemic shocks has increased to levels not seen since 2001. Progress on the macroeconomic front, together with improved credit evaluations and stricter impairment standards on the bank side, will be critical to help India's banks continue their role as economic growth drivers.
\end{abstract}

Keywords: Financial crisis, Financing bank-corporate dependencies, leverage, corporate performance, India.

JEL Classification Numbers: D22, G01, G30, G32, F30.

\section{INTRODUCTION}

The financial sector in the Indian economy has had an uneven history. The story of the postindependent (i.e., post-1947) Indian financial sector can perhaps be portrayed in terms of three distinct phases-the first phase spanning over the 1950s and 1960s exhibited some elements of instability associated with laissez faire but underdeveloped banking; the second phase covering the 1970s and 1980s began the process of financial development across the country under government auspices but which was accompanied by a degree of financial repression; and the third phase since the 1990s has been characterized by gradual and calibrated financial deepening and liberalization. While the present paper is devoted primarily to the period since the 1990s, we also provide a brief account of the earlier two phases. ((IMF Working paper, Indian financial sector, structure, trends and turns-2017)

The Reserve Bank of India (RBI) was founded in 1935 under the Reserve Bank of India Act "...to regulate the issue of Bank Notes and keeping the reserves with a view to securing monetary stability in India and generally to operate the credit and currency system of the country to its advantage." Apart from being the central bank and monetary policy authority, the RBI is the regulator of all banking activity, including non-banking financial companies, manager of statutory reserves, debt manager of the government, and banker to the government. At the time of independence in 1947, India had 97 scheduled4 private banks, 557 "nonscheduled" (small) private banks organized as joint stock companies, and 395 cooperative banks. Thus, at the time of India's independence, the organized banking sector comprised three major types of players, viz., the Imperial Bank of India, joint-stock banks (which included both joint stock English and Indian banks) and the foreign owned exchange banks. The decade of 1950s and 1960s was characterized by limited access to finance of the productive sector and a 
large number of banking failures. ((IMF Working paper, Indian financial sector, structure, trends and turns-2017)

India nationalize its 20 private sector banks in 1969 to 1980 ., and showed classical indications of financial repression, viz., high prevention of banks' investible resources (with allied possessions of crowding out of credit to the private sector), focus to an complex cobweb of administered interest rates, and attended by quantitative upper limit on sectoral credit, as governed by the Reserve Bank of India. Also the commercial banks, there were four other kinds of financial institutions in the Indian financial sector: development finance institutions (DFIs), co-operative banks, regional rural banks and post-offices.

Based on an agrarian setup India carries 1,579 urban co-operative and 94,178 rural cooperative banks as well mainly to give credit facilities to village farmers. . A bulk of these banks tend to operate in a single state, and they are controlled and overseen by state-specific Registrars of Cooperative Societies (RCS), along with overall oversight by the Reserve Bank of India. Thus there has been dual control of regulation and supervision of co-operative banks between the state-specific RCSs and the RBI, which has often been problematical. Regional Rural Banks (RRBs) were established in 1975 as local level banks in different states of India. Another entity the Post Office Savings Bank (POSB) has a customer base of about 330 million account holders as on March 2015 (Government of India, 2016) thereby contributing significantly to financial inclusion on the deposit side. The POSB offers only deposit and remittance facilities but not any credit to account holders.

The Bombay Stock Exchange, the first stock exchange in India, was founded in 1875. However, by modern standards, the Indian equity market was still quite underdeveloped till about the late 1980s. It was governed by an archaic regulatory structure whereby the Controller of Capital Issues (CCI) in the Finance Ministry was the effective equity market regulator. Government bonds were available on tap at a fixed coupon and primarily catered to deficit financing of the government. Draconian foreign exchange controls resulted in a virtually nonexistent market for foreign exchange. ((IMF Working paper, Indian financial sector, structure, trends and turns-2017)

Moreover, the government thrust on infrastructure investment through public-privatepartnerships (PPP) led to huge new debt being contracted by highly leveraged Indian corporate entities investing in infrastructure. Financial inclusion has been a concern in India since at least the early part of the last century. The setting up of a postal savings bank, rural and urban co-operative banks, regional rural banks, and the nationalization of banks, were all done at different points in time to promote financial inclusion. Despite all the decades of social sector banking and success in spreading the banking network, there has been evidence that poorer sections of the society have not been able to access financial services adequately from the organized financial system (NABARD, 2008). One of its major corner-stones is the presence of stipulations on "priority sector lending" by the commercial banks. For this purpose, priority sector includes the following categories, viz., agriculture; micro, small and medium enterprises; export credit; education; housing; social infrastructure; renewable energy; and others (like weaker section of the community). Indian commercial banks are required to lend 40 percent of their credit to the priority sector. Foreign banks with 20 branches and above also have to achieve the 40 percent total within a maximum period of five years over April 2013-March 2018 as per the action plans submitted by them and approved by RBI. Besides, there are subtargets within this overall 40 percent target; illustratively, 18 percent has to be disbursed to agriculture while 7.5 percent has to be disbursed to the small and medium enterprises. ((IMF Working paper, Indian financial sector, structure, trends and turns-2017) 
In recent times, introduction of Priority Sector Lending Certificates (PSLCs) have enabled banks to achieve the priority sector lending target and sub-targets by purchase of these instruments in the event of shortfall. Further, commercial banks can also invest the amount of their shortfalls in the Rural Infrastructure Development Fund (RIDF) run by NABARD. There are several diverse dimensions of financial inclusion such as, income, region/province, caste, gender, economic size of the firm/household, and type of economic activity. The All India Debt and Investment Survey of December 2013 indicated that during 2012-13, non-institutional sources (i.e., sources of credit other than government, banks, insurance companies, pension funds, financial companies, and so on) continued to play a major role in providing credit to the rural households-about 19 percent of all rural households have acquired credit from noninstitutional sources. Several Nonbanking financial companies (NBFCs) are considered to be systemically important and the RBI is planning on focusing its regulatory efforts on them.

The regulatory and supervisory regime for banks, insurance, and securities markets is well developed and largely in compliance with international standards. Areas for improvement include greater de jure independence of regulatory agencies; consolidated supervision of financial conglomerates; reductions in the large exposures and related-party lending limits in banks; stronger valuation and solvency requirements in insurance; and the monitoring of corporations' compliance with reporting, auditing, and accounting requirements for issuers.

Further steps are needed to promote deeper fixed income markets, including a prudent reduction in banks' minimum statutory holdings of government bonds in line with evolving international liquidity requirements, which would support liquidity in secondary markets and the development of a yield curve; and upgrading the corporate insolvency framework. Use of capital markets to refinance infrastructure loans would help alleviate pressures on banks.

\section{How the system works?}

Growth in bank credit in Financial Year 2017, at 5.1\%, has turned out to be the slowest in over 60 years as state-owned banks burdened with bad loans struggled to find safe avenues to lend. The last time loans grew slower than this was in 1953-54 when bank credit growth had slowed down to 1.7\%. (Mayur Shetty, TNN, Times of India, Apr 15, 2017)

Table -1 India's Fiscal Deficit \% of GDP for years

\begin{tabular}{|l|l|}
\hline Year & Fiscal Deficit (\%) \\
\hline $2012-13$ & $8.2 \%$ \\
\hline $2013-14$ & $5.5 \%$ \\
\hline $2014-15$ & $5.3 \%$ \\
\hline $2015-16$ & $4.6 \%$ \\
$2016-17$ & $4.2 \%$ \\
\hline
\end{tabular}

Source: World Bank Data

If look at the data, India's fiscal deficit is showing a down ward trend since 2012 onwards. There is a discrete data may be required for 10 years if we wish to have a conclusion ion this ground.

\section{Liquidity Requirements}

If the banking credit to the private sector is about 70 percent of GDP and more, then the country has a relatively well developed financial system. The amount of credit can even exceed 200 percent of GDP in some very advanced economies. In some poor countries, the credit could be less than 15 percent of GDP. In these countries, firms and households essentially do not have access to credit for investment and various purchases. 
Commercial banks are required to hold substantial precautionary buffers of government securities. RBI uses the CRR (set at 5.5 percent) and SLR (set at 24 percent) to provide banks with sizeable buffers of low-risk assets while also supporting the government's financing needs. RBI's flexible use of SLR and CRR, together with a range of other measures, enabled banks to cope well with liquidity pressures during the global crisis. Most holdings of government securities, however, are not available to meet liquid needs in normal times as they have to be held on a continuous basis to meet SLR requirements.

The authorities have taken a number of steps recently to promote the development of fixed income markets but further measures would be desirable. In particular, gradually reducing the Statutory Liquidity Ratio (SLR) in line with evolving international liquidity requirements would support not only deeper capital markets but also systemic liquidity management and monetary transmission. Further use of capital markets to refinance infrastructure loans would help alleviate pressures on public banks - so far, the main lenders to the infrastructure sector.

India is going through a drastic change in the bank rate, Cash Reserve Ratio and Statutory Liquidity Ratio (Reserve bank's rates for lending) since 1990 onwards. During 1991, the bank rate was $11 . \%$, CRR was $15 \%$ and SLR was $38 \%$.The following table will update us about the changes in the ratios since, during 2010 onward.

Table 2-Liquidity Data -India

\begin{tabular}{|l|l|l|l|}
\hline Year & Bank Rate (\%) & CRR (\%) & SLR (\%) \\
\hline 2010 & 8 & 6 & 24 \\
\hline 2011 & 9 & 4.25 & 23 \\
\hline 2012 & 8.75 & 4 & 23 \\
\hline 2013 & 9 & 4 & 22 \\
\hline 2014 & 7.75 & 4 & 22 \\
\hline 2015 & 7.75 & 4 & 21.50 \\
\hline 2016 & 7 & 4 & 21.25 \\
\hline 2017 & 6.75 & 4 & 21 \\
\hline
\end{tabular}

Source: Handbook of Statistics of Indian Economy, Reserve Bank of India Note: (CRR and SLR as Percent of Net Demand and Time Liabilities)

\section{Bank credit to the private sector}

Domestic credit provided by the banking sector includes all credit to various sectors on a gross basis, with the exception of credit to the central government, which is net. The banking sector includes monetary authorities and deposit money banks, as well as other banking institutions where data are available (including institutions that do not accept transferable deposits but do incur such liabilities as time and savings deposits). Examples of other banking institutions are savings and mortgage loan institutions and building and loan associations. Bank credit in India and other countries is defined as the credit extended by the banking institutions to the private sector only: both firms and households. It does not include lending to the government. Credit is essential for the economy to function well. It funds new investments and allows people to purchase houses, cars, and other items. Of course, excessive lending and borrowing usually end up in financial crises but, in principle, credit availability is good for economic development. International Monetary Fund, International Financial Statistics and data files, and World Bank and OECD GDP estimates -2016)

Macro credit risk tests indicate that the system overall is resilient to aggregate increases in credit risk. Under various risk scenarios, the banking system remains adequately capitalizedwith a sharp initial NPA increase declining gradually with the recovery of GDP. Liquidity stress 
tests indicate that the banking system could withstand severe funding and market liquidity shocks, for instance coming from a reversal of capital flows, under the assumption that the SLR is used in repos with RBI with a 5 percent haircut. Tests included a sudden, substantial withdrawal of funds over a five-day and 30-day period, as well as tests on maturity mismatch and roll-over risk. Most banks pass several liquidity stress tests, with maturity mismatches presenting the highest risk. Single-factor sensitivity analyses suggest that the system could withstand a range of shocks. (International Monetary Fund, International Financial Statistics and data files, and World Bank and OECD GDP estimates -2016)

Credit risk-including exposures to agriculture, power, telecommunications, and real estateis the main source of vulnerability but appears to be manageable given high initial levels of capital and good profitability; only a few small banks would appear in need of recapitalization. Shocks to market risks (interest rate, foreign exchange, equity price risks) have low impact largely due to strict regulations that limit maturity gaps, net foreign currency exposures, and equity market exposures. Domestic credit to private sector refers to financial resources provided to the private sector by financial corporations, such as through loans, purchases of non- equity securities, and trade credits and other accounts receivable that establish a claim for repayment. For some countries these claims include credit to public enterprises. The financial corporations include monetary authorities and deposit money banks, as well as other financial corporations where data are available (including corporations that do not accept transferable deposits but do incur such liabilities as time and savings deposits). Examples of other financial corporations are finance and leasing companies, money lenders, insurance corporations, pension funds, and foreign exchange companies. (International Monetary Fund, International Financial Statistics and data files, and World Bank and OECD GDP estimates -2016)

Table 3 - India - Bank credit to the private sector ((\% of GDP))

\begin{tabular}{|l|l|}
\hline Year & Value \\
\hline 1960 & 7.95 \\
\hline 1961 & 8.63 \\
\hline 1962 & 9.1 \\
\hline 1963 & 9.23 \\
\hline 1964 & 8.65 \\
\hline 1965 & 9.4 \\
\hline 1966 & 9.64 \\
\hline 1967 & 9.24 \\
\hline 1968 & 9.95 \\
\hline 1969 & 10.54 \\
\hline 1970 & 11.39 \\
\hline 1971 & 12.66 \\
\hline 1972 & 13.1 \\
\hline 1973 & 13.27 \\
\hline 1974 & 13.09 \\
\hline 1975 & 15.14 \\
\hline 1976 & 18.13 \\
\hline 1977 & 18.29 \\
\hline 1978 & 19.96 \\
\hline 1979 & 21.24 \\
\hline 1980 & 20.82 \\
\hline
\end{tabular}




\begin{tabular}{|l|l|}
\hline 1981 & 21.51 \\
\hline 1982 & 22.99 \\
\hline 1983 & 23.2 \\
\hline 1984 & 24.61 \\
\hline
\end{tabular}

\begin{tabular}{|l|l|}
\hline 1985 & 24.9 \\
\hline 1986 & 26.15 \\
\hline 1987 & 25.73 \\
\hline 1988 & 25.62 \\
\hline
\end{tabular}

\begin{tabular}{|l|l|}
\hline 1989 & 26.95 \\
\hline 1990 & 25.25 \\
\hline 1991 & 24.14 \\
\hline 1992 & 25.03 \\
\hline
\end{tabular}

\begin{tabular}{|l|l|}
\hline 1993 & 24.05 \\
\hline 1994 & 24.15 \\
\hline 1995 & 23.97 \\
\hline 1996 & 22.82 \\
\hline
\end{tabular}

\begin{tabular}{|l|l|}
\hline 1997 & 23.72 \\
\hline 1998 & 23.87 \\
\hline 1999 & 24.82 \\
\hline 2000 & 23.72 \\
\hline
\end{tabular}

\begin{tabular}{|l|l|}
\hline 2001 & 23.87 \\
\hline 2002 & 24 \\
\hline 2003 & 25.77 \\
\hline 2004 & 28.72 \\
\hline
\end{tabular}

\begin{tabular}{|l|l|}
\hline 2005 & 29.01 \\
\hline 2006 & 32.74 \\
\hline 2007 & 32.05 \\
\hline 2008 & 36.68 \\
\hline 2009 & 40.64 \\
\hline 2010 & 44.57 \\
\hline 2011 & 46.22 \\
\hline 2012 & 50.06 \\
\hline 2013 & 51.39 \\
\hline 2014 & 51.98 \\
\hline 2015 & 52.21 \\
\hline 2016 & 51.89 \\
\hline 2017 & 52.39 \\
\hline
\end{tabular}

Source: World Bank Data, (World Bank -Development Indicators-2017) 
The World Bank provides data for India from 1960 to 2015 Bank credit to the private sector as percent of GDP. The average value for India during that period was 25.61 percent with a minimum of 7.95 percent in 1960 and a maximum of 52.39 percent in 2017.

\section{Market capitalization of business and Insurance sector}

India is really advanced its financing through the way of issue of securities in stock market or Initial public offering India has made significant progress in the implementation of the International Organization of Securities Commissions (IOSCO) Principles since the 2001 assessment. Securities and Exchange Board of India (SEBI) has now broad regulatory, licensing, investigation, supervision, and enforcement powers. Based on its strong legal framework, SEBI has developed robust regulations for different types of market participants, including issuers, collective investment schemes, brokers, portfolio managers, underwriters, and recognized regional stock exchanges (RSEs) - although in the medium term its approach to 27 capital requirements should become more risk-based. Efforts made by SEBI in recent years to build a robust market surveillance system as well as separate investigation and enforcement departments have translated into effective enforcement of unfair trading practices, such as market manipulation and insider trading. Insurance is another mode of financing businesses in India. The insurance regulatory authority has a clear mandate and is a leader among emerging markets in areas such as licensing, consumer protection, market oversight, and transparency. (Handbook on Indian insurance statistics: 2014-15, Hyderabad: IRDA)

\section{The Monitory /fiscal indices Matters?}

The combination of monetary policy and macro prudential instruments had a strong effect on the credit cycle. There is also anecdotal evidence that higher borrowing costs, as a result of higher interest rates and tighter capital risk weights and provisioning requirements, prompted developers and NBFCs to turn to the corporate bond market and to borrow abroad. Hence borrowers were able to circumvent, to some extent, the macro- prudential measures. The impact of coordinated policy action is apparent even if the effect of the macro -prudential instruments is not easily distinguishable from that of general monetary tightening. (Financial Express, 2012).

Some of India's economic resilience was supported by increases in government spending initiated before the crisis; another part was driven by a push towards infrastructure spending, which began around 2004, and was supported by credit growth, mainly through public sector banks (PSBs). During that period, corporate borrowing as a share of GDP reached new heights year after year

External corporate funding creates potential feedback loops between corporate vulnerabilities and external shocks. Indian corporates rely on foreign sources for more than one-fifth of their debt financing, including ECBs, trade credits, and bonds. In addition, debt service payments over the upcoming two years are forecast to come in at higher levels than during the GFC, and their maturity profile has shortened. About 35 percent of ECBs are estimated to be hedged with financial instruments, with the scope of 'natural', business-related hedges difficult to estimate (Financial Express, 2012).

Based on these four indicators (ICR, profitability, liquidity and leverage), derived from the Center for Monitoring Indian Companies (CMIE) Prowess database (covering the period 1990/91-2012/13), we find that corporate vulnerabilities of Indian non-financial corporations are at their highest levels since the early 2000s.We gauge India's corporate health based on four frequently-used indicators: interest-cover ratio (ICR), profitability, liquidity, and leverage. ICR and profitability are indicators of a firm's performance over a shorter period like a quarter 
or a year, assessing the degree to which current activities allow the funding of interest expenses, or whether a firm's combined operating and financial activities are self-funding, respectively. Both measures are essentially snapshots, taken at a particular point in time. An ICR below one, or a lack of profitability, does not indicate that insolvency is imminent. Firms can have investments that are liquid or can be easily used as collateral for borrowing, open credit lines, or other sources of funding which could carry them through. Nevertheless, low levels of ICRs are found to be a good indicator of systemic vulnerabilities. The ICR is usually defined as EBIT or EBITDA (Earnings before Interest, Taxes, Depreciation and Amortization) divided by interest expenses. (Financial Express, 2012).

Core financial metrics of corporates can reveal their ability to weather financial stresses, which are often caused by macroeconomic factors, as well as provide an indication of firms' ability to adapt to changes in their business environment. For example, changes in exchange rates or interest rates can adversely affect a firm's equity and also its debt servicing capacity. Anticipating potential problems, lenders may choose not to roll over debt, or not to provide new credit to companies that may become distressed.

\section{How small businesses are financed?}

SME loans are specially created loans for the small businesses. These are designed to be in tune with unique requirements which small businesses encounter during various phases of their business. Small finance banks are a type of niche banks in India. Banks with a small finance bank license can provide basic banking service of acceptance of deposits and lending. The aim behind these to provide financial inclusion to sections of the economy not being served by other banks, such as small business units, small and marginal farmers, micro and small industries and unorganized sector entities.

Existing non-banking financial companies (NBFC), micro-finance institutions (MFI) and local area banks (LAB) [Local area banks are nonscheduled banks. They were set up with the twin objectives of providing an institutional mechanism for promoting rural and semi urban savings and for providing credit for viable economic activities in the local areas. They were established as public limited companies in the private sector, They are promoted either by individuals, corporate, trusts or societies, The minimum paid up capital of such banks was Rs. 100 crores, The promoter's contribution should be at least Rs.40 crores (This also looks incorrect),Local area banks can operate and open their branches in a maximum of three geographically contiguous districts, They are governed by the provisions of Reserve Bank of India act 1934, Banking Regulation act 1949 and other relevant statutes. They are to be registered as public limited companies under the Indian company's act 1956.

Since they are non-scheduled banks, they cannot borrow funds from Reserve Bank of India like other scheduled commercial banks] are allowed to set up small finance banks. The promoters should have 10 years' experience in banking and finance. The promoters stake in the paid-up equity capital will be $40 \%$ initially which must be brought down to $26 \%$ in 12 years. Joint ventures are not permitted. Foreign shareholding will be allowed in these banks as per the rules for FDI in private banks in India. The banks will not be restricted to any region. $75 \%$ of its net credits should be in priority sector lending and $50 \%$ of the loans in its portfolio must in 25 lakh range

After extensive trial and research the pilot programme was launched Twenty Five years ago in 1992. The Self Help Group - Bank Linkage Programme (SHG-BLP) was an innovation harnessing the synergy of flexibility of informal system with the strength and affordability of formal system. Three radical innovations were introduced through the RBI/NABARD 
guidelines on SHG-BLP: Acceptance of informal groups as clients of banks - both deposit and credit linkage Introduction of collateral free lending, and Permission to lend to group without specification of purpose/ activity/project This savings led and door step credit delivery mechanism based on social collateral started making immediate inroads backed by an enabling policy environment and support from some national level institutions and multilateral agencies. NABARD's experiment in SHG-BLP established the credibility of groups as a bankable proposition and rural people capable of financial discipline. It created a new set of clientele with untapped appetite leading to several NGOs acting as financial intermediaries for onlending to groups buoyed by the success of SHG-BLP. A new breed of micro lenders was born, the Micro Finance Institutions. As per MFIN, as on 31.03.2017, the Microfinance industry has a total loan portfolio of R106, 916 crore. As we celebrate the Silver-Jubilee year of the movement, it is heartening to share visible improvements in all aspects of the movement as compared to last year. During 2016-17, despite the impact of demonetization on credit disbursement and repayments, combined efforts and initiatives of NABARD, banks, SHPIs, NRLM and Government agencies have given great boost to the SHG-BLP movement. There was a net addition of 6.73 lakh SHGs during the year increasing the number of SHGs having savings linkage to 85.76 lakh as on 31 March 2017. The savings outstanding of SHGs with banks as on 31 March 2017 has reached an all-time high of R16114.22 crore. During the year, banks have disbursed loan of R38781.16 crore, recording 4\% increase over the last year despite the impact of demonetization which slowed down loan disbursement post October 2017. The total bank loan outstanding to SHGs also increased by 7.81\% and stood at R61581.30 crore against R57,119 crore as on 31 March 2016. The gross NPA of bank loans to SHGs marginally increased by about 5 basis points from $6.45 \%$ as on 31 March 2016 to $6.50 \%$ as on 31 March 2017. This was achieved in a year when there was overall deterioration in quality of assets and mounting NPAs in the banking sector. (Report on Trend and Progress of Banking in India 2014-15)

\section{CONCLUSION}

Despite the relentless efforts of Government of India and RBI in creating and supporting enabling environment for increasing the outreach of formal financial services to cover the marginalized population, informal sector continued to rule the roost till quite some time. The major cause was the information asymmetry that plagued the formal banking system vis-à-vis the village money lender. What was needed was to break the monopoly of door-step availability of credit by the informal sources at the time of crisis. That's where the Self Help Group concept scored. It combined the flexibility and availability of informal sources with the transparency of institutional credit. (Report on Trend and Progress of Banking in India 2014-15, $R B I)$

Despite this, the rise in number of SHGs credit linked and quantum of loan disbursed during the year is very positive for SHG-BLP. The average loan disbursement per group during 201617 was R2.04 lakh, a slender rise from R2.03 lakh during the previous year, against the y-o-y rise of 20\% in 2015-16. Southern Region however continued to have the distinction of having highest per SHG average credit disbursement of R2.73 lakh with a 5\% rise over previous year. North Eastern Region (16\%) and Eastern Region (12\%) recorded a rise in the average credit disbursement whereas other Regions have witnessed a fall .Among the States, the average credit disbursement per SHG declined over previous year significantly (25\% and above) in case of Gujarat, Uttar Pradesh, Madhya Pradesh, Uttarakhand and Punjab. Maharashtra (15\%) and Chhattisgarh (11\%) also witnessed moderate fall in average loan disbursement while it was a slender fall (less than 5\%) in States like Tamil Nadu, Karnataka, Haryana, Himachal Pradesh, Rajasthan, Odisha and Jharkhand. In North Eastern Region, States like Manipur, Sikkim and Tripura disbursed lower average loan during the year while other States have recorded a rise. Among major States, average credit disbursed per SHG was in the region of R3 lakhs for Goa 
(R3.19 lakh) and Telangana (R3.02 lakh) followed by Kerala (R2.96 lakh) and Andhra Pradesh (R2.89 lakh). ("Financial Inclusion in India: A Glass Half Empty or Three Quarters Full?" Paper 6 in Mohan (2011).

It is fact that non- banking financial sector is playing a great role in financing the firms in India. Moreover, many firms are not get avail to credit from banks can get along with non-banking sector to fix their financial requirements. The future of non-banking sector in India would be more inclusive rather banking sector.

\section{References}

Financial Express, 2012

Government of India (1998): Report of the Committee on Banking Sector Reforms (Chairman: M Narasimham), New Delhi: Government of India.

Government of India, (2009): A Hundred Small Steps: Report of the Committee on Financial Sector Reforms (Chairman: Raghuram Rajan), New Delhi: Planning Commission.

Government of India (2015): Report of the Committee to Recommend Measures for Curbing Mis-selling and Rationalising Distribution Incentives in Financial Products" (Chairman: Sumit Bose) available at http://finmin.nic.in/reports/Final Report Committee on_Incentive_Structure.pdf

Government of India (2016): Annual Report: 2015-16 - Department of Posts, available at http://www.indiapost.gov.in/Report/FinalPostAnnualReportEnglish2015-16.pdf

International Monetary Fund (2013): India: Financial Sector Assessment Program—Detailed Assessments Report on IAIS Insurance Core Principles, available at http://www.imf.org/external/pubs/ft/scr/2013/cr13265.pdf

International Monetary Fund (2013a): Guidance Note For The Liberalization and Management Of Capital Flows, available at https://www.imf.org/external/np/pp/eng/2013/042513.pdf

International Monetary Fund (2014): Annual Report on Exchange Arrangements and Exchange Restrictions 2014, Washington DC: IMF.

International Monetary Fund Working paper (2017) Indian financial sector, structure, trends and turns-IMF

ICRA (2016): Mutual Fund Screener (for the Quarter ended March 2016), available at https://mutualfundindia.com/Images/Research/PdfPaths/7a11b786a2c942b690db34e7c 39db743Mutual\%20Fund\%20Screener\%20-\%20Mar\%202016.pdf

IRDA (Insurance Regulatory and Development Authority of India) (2007): "History of insurance in India", available at https://www.irdai.gov.in/ADMINCMS

IRDA (2015): Handbook on Indian insurance statistics: 2014-15, Hyderabad: IRDA.

Mayur Shetty, TNN, Times of India, Apr 15, 2017

Mohan, Rakesh (2005): 'Financial Sector Reforms in India: Policies and Performance Analysis', Economic and Political Weekly, 40 (12): 1106-21.

Mohan, Rakesh (2006): “Financial Sector Reforms and Monetary Policy: The Indian Experience”, Paper presented at the Conference on Economic Policy in Asia at Stanford, organized by Stanford Center for International Development and Stanford Institute for Economic Policy Research, on June 2, 2006, available at http://www.rakeshmohan.com/docs/RBIBulletinJuly2006-1.pdf

Mohan, Rakesh (2011): Growth with Financial Stability: Central Banking in an Emerging Market, Delhi: Oxford University Press. 34

Mohan, Rakesh (2011a): “Development of Banking and Financial Markets in India: Restoring Growth while containing Risk", Paper 4 in Mohan (2011).

.Mohan, Rakesh (2011b): “Financial Inclusion in India: A Glass Half Empty or Three Quarters Full?”, Paper 6 in Mohan (2011).

Mohan, Rakesh and Muneesh Kapur (2011): "Managing the Impossible Trinity: Volatile Capital Flows and Indian Monetary Policy", Paper 8 in Mohan (2011).

Mohan, Rakesh and Partha Ray (2011): "Development of the Indian Debt Market", Paper 5 in Mohan, (2011). 
.NABARD (National Bank for Agriculture and Rural Development) (2008): Report of the Committee on Financial Inclusion (Chairman: C Rangarajan), Mumbai: NABARD.

RBI (2003): Report on Currency and Finance, 2001-02, Mumbai: RBI.

RBI (2007): Report on Currency and Finance, 2005-06, Mumbai: RBI.

RBI (2008): Report on Currency and Finance, 2006-08, Volumes 1 \& 2, Mumbai: RBI.

RBI (2009): India's Financial Sector: An Assessment, available at https://www.rbi.org.in/scripts/PublicationReportDetails.aspx?ID=544

RBI (2014): Report of the Committee to Review Governance of Boards of Banks in India, (Chairman: PJ Nayak), Mumbai: RBI.

RBI (2014a): Financial Stability Report, 2013-14, Issue No. 10.

RBI (2015): Report on Trend and Progress of Banking in India 2014-15, available at https://www.rbi.org.in

World insurance in 2014: back to life, available at http://media.swissre.com/ documents/sigma4_2015_en.pdf 